\title{
Gender Sensitivity and the Objectification of Females in Pop Nigerian Music Videos
}

\author{
Ubong-Abasi Usoroh ${ }^{1 *}$ \\ School of Media and Communication, Pan-Atlantic University, Lagos, Nigeria
}

\begin{abstract}
This paper assessed existing Nigerian Music Videos for female sexual objectification. Its intent was to discover if and how Nigerian pop music videos objectify the female gender, evaluate the effect of objectification on Nigerian females and to proffer solutions (if necessary) from the perspective of content creators (music video makers) to better the case of female objectification and presentation of gender sensitive issues in Nigerian Entertainment Media while maintaining a positive image of the country and females within Nigeria. Adopting content analysis as a preliminary measure for perusing pop music videos within a time frame, it took a deep dive into assessing pop Nigeria music videos for instances of female objectification and then questions female audiences on the influences these portrayals could possibly have on them. Findings revealed a concerning height of female objectification and influences which calls for attention towards issues surrounding female representation in music videos and the impact it is having on females in Nigeria.
\end{abstract}

Keywords: Female objectification, gender sensitivity, objectification of females in music videos, females in media, Nigerian music videos

DOI: $10.7176 / \mathrm{JCSD} / 64-03$

Publication date:May $31^{\text {st }} 2021$

\section{Introduction}

The focus on gender sensitive issues has within the past few decades been on a steady increase nationally and globally even as societies within different nations attain different levels of enlightenment as regards gender and sexuality issues. These gender sensitive issues remain broad and are exemplified even in trends such as the feminist trends, LGBTT movement and rights, body shaming discusses, gender roles within different social institutions in societies and objectification/sexual objectification of genders in society and in media. These have become problems hinged on societies advancements and perceived enlightenment. Being a social area of concern, these issues permeate fabrics and all sectors of society. While some of these observed problems require some form of heightened attention when assessed ethically, morally and religiously, others appeal ideally as interesting perspectives from which some sets of individuals view and partake in life.

In this paper, the crux of focus on Gender sensitivity attempts to highlight and address the idea or perspective that media's portrayal of the female gender and gender generally in Nigeria's contemporary music video sphere may be the reason behind the worsening perception of the female gender and her essence and may as well be the major correctional tool needed to fix misconceptions and misinterpretations along gender perspectives and pathways. It is pertinent that the focus be narrowed to the female gender, this is not an attempt to lean towards any form of bias even though studies within this field have perceivably been noted to be female centred, it is however based on the understanding that the female gender remains the most negatively portrayed and sexually objectified gender in society and media (Szymanski et al, 2011, pg10).

This paper aims to investigate existing views in the academia on female sexual objectification. It intends to discover if and how Nigerian pop music videos objectify the female gender, evaluate the effect of objectification on Nigerian femles and to proffer solutions (if necessary) from the perspective of content creators (music video makers) in an attempt to better the case of female objectification and presentation of gender sensitive issues in Nigerian Entertainment Media while maintaining a positive image of the country and females within Nigeria.

\section{Defining Variables \\ Gender Sensitivity}

Gender sensitivity in its operational nature, tracks and covers the assimilation and record keeping of social and cultural causes of gender discrimination and biases evident in different facets of the social life; and with clear references to the male hegemony and male chauvinistic nature of most societies (Sribar, 2015). As operationalized by the European Union, Gender sensitivity's definition covers the conscious efforts to be aware of gender differences, issues and inequalities while adopting these consciousness in actions and strategies (Definedterm, N.D.). While the aim of gender sensitivity borders on the maintenance/sustenance of the respect, reverence and integrity of genders, it does further hinge its tenets with the gender equality trend as the premise proposing equity, equal respect and balance with regards engagement and dealings with all genders and the human person in societies where the female gender is unequally regarded. For Obiunu (2013), Gender sensitivity references the intensity of awareness as well as appreciation one must maintain as prerequisite for addressing 
gender differences between male and female.

\section{Sexual Objectification}

Sexual objectification should be understood as the (visual) fragmentation/ dismemberment of the female gender's body into an assemblage of body parts or perception of the female as a docile and dormant body that appeals sexually to the onlooker who then ignores the personality behind the body while valuing and understanding the body part(s) or the body as the essence and total representation of the being in focus (Calogero, 2012).

\section{Pop Nigerian Music Videos}

The concept of pop being popular Nigerian music revolves around music that resonates with the masses - that is indigenous to a specific community (Ojukwu et al, 2016). These forms of music utilize everyday slangs, idioms and clichés understood by a majority of the masses and often used by the populace everyday (Ojukwu et al, 2016). Although pop Nigerian Music Videos had at some point been equated to music for the wayward, it does appear to be gaining traction and accolades on the international scene (Ekwueme, 2004).

\section{Statement of the Problem}

Gruber and Grube (2000) had explained that the exposure of teenagers and youths to sexual contents in electronic media has become alarming and more often than not, affect their behaviours, attitudes and beliefs. Along this lane of thought, there is a dwindling decency in music videos as it relates to gender sensitive issues. Media sexually objectifies women even as it is sometimes perceived as a media/cultural imperialist or global trend causing gradual decadence of social, cultural and moral norms within a Nigerian context. Portrayal of women in music video remains poor as it eventually weakens moral fabrics of society. The weakening of moral norms then plays out in the types of clothes females choose to wear, their walking steps, perception of self as well as their behaviour around males. Evidently, females are adversely affected as they in turn objectify self, dress indecently while some men have been reported to be uncontrollable and pushed to assault females by way of rape, indecent touches, etc. This has serious negative implications for the family as a central social institution as objectifying women in music videos taints young boys and girl's understanding of decent and diffuses social norms, cultures and traditions. The aftermath of these forms of influences has implications for government as a regulatory body as they may have to deal with mitigating the surge in teenage pregnancy, reported rape cases, rising rates of depression and anorexia in females etc. which further delves a devastating economic blow on government as they may have to intervene at some point.

While it is clear that media objectifies women, the researcher was unable to find literature that has been able to assess the Nigerian pop music scenario to identify how these videos allegedly objectify women in a Nigerian context, how sexually objectifying females affect females within a Nigerian context and what can be done to salvage the situation. Therefore this study intends to identify how females are objectified in Nigerian pop music spheres (if any), its effect on females and recommendations to help mitigate and totally eradicate the trend. This study problematizes and focuses primarily on the objectification of women in music videos as it negatively impacts female's health, psychology and behaviour as an aftermath of self-objectification. The aftermath of continuous objectification of females in music videos further contributes to the degeneration of society's values and norms, disrespect for the female gender and disregard for her value away from her body. This effort should aid government, administrators, regulatory bodies and other stakeholders understand the nature, dynamics and consequences objectification in music videos on society while furnishing a reader with ideas to aid regulation.

\section{Justification for Study}

This paper agrees with the perspective that American entertainment media and other media have through time objectified the female gender and these have an effect on viewers and society. But then, due to the uniqueness of each country's media, objectification and poor portrayals may not be attainable in all media. Also, this trend may have changed considerably considering the awareness on gender and sexuality talks, studies and researches that may have influenced laws and policies in different countries, their media and other sectors within these countries.

For a proper grounding it is pertinent that the paper attempts to identify how Nigerian Pop Music Videos Objectify females as a fundamental premise needed to further the objectives of this paper. To assess and evaluate the premise of the framing theory and that of the objectification theory, it is worthy that it be tested in a context which in this instance will be Nigeria and its entertainment media - a content analysis of ten (12) contemporary music videos spurned between 2011 and 2018 for instances of sexual objectification of the female gender. The aim is to identify and assess (if any) how females are objectified in Pop Nigerian Music Videos Spurned between 2011 and 2018 .

Furthermore, a population of females will be surveyed in a bid to assess the effect of objectification on females in Nigeria. Being that the initial phase of this paper aims to identify if and how Nigerian pop music 
videos objectify the female gender, the aim will not be to evaluate the trend or rate of its increase or decrease, it is will rather be an attempt to identify (if any), its existence in Nigeria Entertainment media and the shapes instances of objectification take. This is in a bid to inquire and establish through research and empirical evidence (In a pilot study nature) that Nigeria Pop Music Video does or does not objectify women. This part would eventually provide the paper with the basis to further research into sexual objectification's impact on females. The first phase is then an introductory inquiry and a test study into issues of gender sensitivity - objectification and stereotypical portrayal of women in Nigeria's Pop Music Video Space.

\section{Objectives of the Study}

1. Test Samples of Nigerian Pop Music to see if they objectify females

2. Discover how Nigerian Pop Music Videos dominantly objectify females

3. Discover how sexual objectification in Nigerian Pop Music Videos affects females

4. Proffer Solutions

\section{Research Questions}

1. Does Nigerian Pop Music Video Objectify females?

2. How are females sexually objectified in Nigerian Pop Music Videos?

3. How does sexual objectification of females in Nigerian Pop Music Videos affect females?

4. What possible strategies can help mitigate the anomaly (if any)?

\section{Theoretical Framework}

The Objectification Theory proposed by Barbara Fredrickson and Tom-Ann Roberts (1997) establishes the premise that due to sexual objectification of females by media and society, the female gender has been conditioned (by the media and society) to internalize an onlooker's view as the most relevant perspective needed to define her worth; this in turn catalyses a consequent culture of obsessed self-monitoring/consciousness, escalated feeling of anxiety and shame, reduced awareness of her inner person and essence, eating disorders, mental and health risks, depression, etc. (Fredrickson and Roberts, 1997). This internalization of the sexual objectification believe and its effect has been termed self-objectification. In context, Balraj $(2015$, p70) stresses that media and the male gender have through time perceived and portrayed women as objects and tools valued for sexual pleasure. These acts are often staged by way of gazes and inspection of the female body (Kaschak, 1992 in Balraj, 2015); as well as through visual dismemberment or focus on specific body parts removed from the person and viewed as the essence or proper representation of her person in its entirety (Bartky, 1990 in Balraj, 2015). The objectification theory here functions to predict methods through which media objectifies the female gender as well as the negative effect sexual objectification of the female by media has on the female gender.

Furthermore, This study will adopt some aspects of the framing theory in an attempt to identify how Nigerian Pop Music Video objectifies the female gender, it will further function to aid analyses and contextualization of issues surrounding objectification of the female gender as a gender sensitive issue in some Nigeria's Pop Music Videos. The framing theory propounded by Erving Goffman highlights the premise that individuals are subjective or at least adopt interpretative designs in their views and perception of the world. This subjective or interpretative schematic view of the world is then transferred into and through every experience or interpretative endeavour/engagement and termed as 'frames' through which individuals make sense of the world and reduce the complexities of reality (Littlejohn and Foss, 2009). There are variations/approaches to the framing theory; which is why Chong and Druckman (2007) submitted that the idea surrounding a frame must be viewed from two perspective - first, as identified in communication as a sender's selective use of words, images, phrases and presentation styles in delivering information about a specific event to an audience (Gamson and Modigliani, 1987, 1989 in Chong and Druckman, 2007, pg100); whereas the second perspective highlights an individual's frame in thought. i.e. the aspects considered by a person to be the most important in a given issue (Goffman 1974 in Chong and Druckman, 2007, p101) In context, the framing theory in media explains that media directs the focus and attention of audiences to certain aspects of an issue in their presentation (Scheufele, 1999). This channelling of view and constructed focus is also in line with the aims and objectives of media owners. Pan and Kosicki (1993) further explain that the manner and style with which issues are presented/contextualized to the audience has an effect and influences the way an audience perceive assimilate, process and interpret the message.

Accordingly, the Framing Theory is a theory that captures the content maker's manipulative prowess and the effect it has on audiences. Its premise maintains the purview that issues of life are selectively presented and with meaning and context to the audience to incite engagements while assimilating meaning. Following the central statement of the framing theory, it does posit that gender sensitive issues or sexual objectification in media does not exist until it is framed or brought into the picture by the moderator through focus on specifically crafted and presented images, sound, video, text, etc. Within the confines of this study, sexual objectification as a 
gender sensitive issue will be traced within samples of music video in a bid to test the efficacy of the theory.

\section{Literature Review}

Scholars from around the globe and especially scholars from the global western and northern hemispheres have been concerned with issues of negative female portrayals, objectification and presentation of gender sensitive issues in Media as an organization/social institution and its content. Examples abound in works of scholars such as Smith \& Cook (2008) who researched into media portrayal of girls and women in media in the United States of America. Using a content analysis approach, the duo reviewed 400 top-grossing films released between 1990 and 2006 and found that females were portrayed in a traditionally stereotypical light i.e. caregivers, emotional, dependent, self-obsessed, objects of/for pleasure, slim, hour glass/Barbie shaped and beautiful. This seemingly patriarchal media also transcends into children's media as seen in Smith et al (2006) study where they reviewed 1,034 children's television shows airing on broadcast and cable outlets. The results were not really different from that of adults as it emphasized that girls were portrayed to be beautiful, sexy, young, caring, calm and playful. These studies emphasize the purview that girls and women are objectified, stereotyped and underrepresented in the media and when a feminine gender is needed; key actresses are sourced based on their looks and perceived by media to be the ideal. One can also deduce from engagement with entertainment media that when women do not meet the ideal body image standard or are portrayed in stereotypically manly behaviours or roles and vice versa, these instances incite comic reliefs, moments of taunts and laughs as well as unease, awe and disbelief across most non-African as well as African Cultures.

Along these lines, Studies such as that of Brown (2010), submits that media's frequent portrayal and coverage of gender and sex has a solid hold on public/private agendas and reinforces an array of relationship and sex related values and norms. These relationship and sex related values may also be inherent or domiciled in stereotypical roles expected of/from each gender in different and given instances. For Instance, Gauntlett \& David, 2008; Zeisler 2008; Lantagne, 2014 have submitted that women in media are often portrayed as submissive; mute; beautiful; sexy and needed to spark sexual tension in media; hour glass and Barbie shaped; hairless except on the head; homemakers; accommodating; indecisive unless linked with a man; soft-spoken; fragile; feeble and in need of protection, attention and reassurance. In reality, these outlooks and behaviours are the media reinforced roles and behaviours expected of the female gender and women in society. Where these attributes are not observed or obvious in a female gender by the society, the feminine nature of the girl child, lady or woman is often called into question in different manners ranging from snubbing, taunts/abusive words to outright violence.

Some studies have implied that stereotypical portrayals of the female gender often speaks to her sexual objectification rather than emphasis on the personality possessed by the body while other studies have also implied that these stereotypical portrayals/ clear objectification of the female gender, affect younger generations and adults who view these messages in media. Example of studies in line with these perspectives include that of L. Monique Ward (2016) who reviewed and analyzed peer-reviewed studies that focused on the effect of sexual portrayal and objectification of the female gender on self. Using a summation of 135 studies from 1995-2015, the results sustained, strengthened and emphasized core/known facts that exposure of women to contents that objectify women within lab environments and real world engagement with these types of content sparked consequences such as escalated levels of self-objectification, dissatisfaction with their body, tolerance for misogyny and gender biased beliefs. Generally Ward's (2016) study reports that continuous exposure to these types of content has an effect on the female gender as it solidifies low self-esteem and diminished humanity. This effect also transcends negative impact on self through to constructed stereotypical expectations conceived by media and society to be normal and obtainable everywhere. These stereotypical portrayals then become what society expects from each gender as it punishes deviance or unconformity to sex and gender-defined and confined portrayals. Furthermore, In a study aimed at the development and psychometric evaluation of the selfobjectification beliefs and behaviour's scale, Lindner and Tantleff-Dunn (2017) assessed 654 women through the use of an online questionnaire to measure self-objectification and other related constructs. With the help of the Self-Objectification Beliefs and Behaviors Scale (SOBBS), the results demonstrated evidence of SelfObjectification ranging from interpersonal sexual objectification, wrong body image perception, disordered eating, depression. This result further rhymed with a secondary study that was aimed at affirming the validity of this study in that the SOBBS scores correlated with public body consciousness, private and public selfconsciousness, self-esteem, and sexual functioning. While the study further pressed for further adaptation of questionnaires and exploration of other avenues to researching objectification of females, its findings confirms the negative effects of objectification of the female gender in media and further confirms the theory of Objectification.

Furthermore, Rooney's (2016) paper highlighted that emerging studies such as that of Miles-McLean (2015), Nadal and Haynes (2012) have discovered that aside readily observed symptoms of sexual objectification on the female gender (symptoms such as depression and anxiety), prolonged exposure to sexual objectification is 
responsible for insidious trauma marked by psychological disorder that is often observed in later stages of most female's lives. These studies further point to the negative effect of sexual objectification of the female gender resulting in self-objectification.

Vance et al (2015), focus is concerned with how print advertisement portray women's bodies (sometimes dismembered and dehumanized into parts and objects) and how viewership of these portrayals relate with the attitudes towards rape and violence towards women. Using questionnaires as a primary data collection approach, this study's result had shown that viewing sexually objectified women had an obvious effect on females and limited effect on the motivations towards rape and further suggests that education towards correcting men's endorsement of rape myths could further decrease the likelihood of rape aimed at women. In Vance et al (2015) paper, there is a perspective that suggests that the objectification of women in print media is the causative reason behind certain immoral female behaviours as well as rape and violence urges in men. Therefore, promoting education to orientate and sensitize men may further reduce the animalistic tendencies inherent in man's desire driven nature.

\section{Methodology 1 - Identifying If and How Nigerian Pop Music Sexually Objectify Females Sample Selection}

This study conducted a media content analysis on ten (12) randomly selected music videos out of thirty (30) most popular classical and contemporary Nigerian Music Videos on Youtube between 2011 and 2018 according to one of the leading websites on Nigerian Entertainment News (Buzznigeria.com). Being that there are innumerable pop Nigerian music Videos in the Market and an analysis of all Nigerian Pop Music videos between 2011 and 2018 would have been near impossible seeing that no formal registry exist to document all of these types of video, BuzzNigeria's platform being one of the most popular websites in Nigeria for either watching or downloading top and most popular pop Nigerian music videos became tenable as the go to website for analysing only the top 12 most popular Nigerian pop Music Videos as a more plausible and achievable objective. The justification for the sample size also emerged from the understanding that top and most popular Nigerian pop music videos had all the elements and intricate qualities of other pop Nigerian music videos within the same genre hence the believe that an analyses of some key and most outstanding samples represents all. The need to further represent the population with 12 of the most popular videos also emerged from the understanding that this analyses appealed a lot more as a pilot study within a content analyses context, hence identifying a theme and a pattern to establish the presence of concerns surrounding sexual objectification of females in Nigerian entertainment videos to aid the advancement of the study applied if its effect was to be further assessed on females who watch or engage with these types of videos within a Nigerian context.

Furthermore seeing that the research needed some form of an unbiased assessment, 12 randomly selected samples were systematically chosen. To ensure unbiased and equal representative selection, all thirty of the most viewed titles were written on a piece of paper, folded and dropped in a container; the entire thirty folded/anonymous titles were then mixed up. Within every 5 random sample counts, 2 were picked and 3 were ignored. In total, twelve (12) out of thirty (30) titles were randomly selected for analyses. This type of sampling within academic research is known as the simple random sampling method used mostly to reflect an even representation of an entire population and to eradicate biases (Yates et al, 2008)

\section{Coding and Media Analysis}

The video contents were coded for varying instances of objectification as will be reflected within a table in the results section. Each of the video was played back fifteen (15) times. Out of this number, (10) ten was used for video analysis/coding whereas (5) five was for analysing the lyrics (audio). For video analysis and coding, each video was played back (10) ten times in slow motion and without sound to enable the researcher focus on the visual task of identifying varying types of objectification. Of this number (10), (7) seven was played in premiere pro software - an Adobe suites video editing software that enables frame by frame playback, slow motion playback, loops, rewind, forward and pause amidst other sophisticated options. The software asset enabled the researcher access and probe each second of picture frames throughout the entire length of each video (motion picture). A supporting and sophisticated video playback software known as the VLC player that is capable of reducing playback speed without distorting visuals was adopted for the remaining (3) three rounds of coding to ensure due diligence in analysing each video to the best of the researcher's investigative abilities. In coding, the analysis coded foregrounded and mid-grounded instances of female sexual objectification within each video. Instances captured in the background were ignored due to blurs (unclear visuals). The remaining (5) five takes were utilized on the lyrics for instances of objectification within the lyrics. For the lyrics, all instances were numbered and given one point where any type of objectification was identified.

This research utilized numeric coding to represent each observed instance of female objectification. These instances and varying types of objectification was deduced while engaging literatures such as that of Balraj (2015), Szymanski (2011), Fredrickson and Roberts (1997), Chong and Druckman (2007), Scheufele (1999) and 
Kosicki (1993).

. The list below reflects how these instances were categorized.

1. Camera/ framed dismemberment

2. Male Gaze/Drooling at body part(s)

3. Use of Female as decorative objects/statue

4. Harassment/ Body Inspection

5. Self-Objectification - Self gaze, touch while seductively dancing or twerking.

6. Portrayal of females in lingerie, bikini or any suggestively nude and revealing attire while dancing.

7. Lyrics

Below is a list of randomly selected songs coded for varying instances of objectification.

\begin{tabular}{|c|c|c|c|c|}
\hline Artist Name & Song Title & $\begin{array}{l}\text { Year of } \\
\text { Release }\end{array}$ & $\begin{array}{l}\text { Video } \\
\text { Length }\end{array}$ & $\begin{array}{c}\text { Current Number of Views on } \\
\text { Youtube }\end{array}$ \\
\hline Davido & If & 2017 & $3: 59$ & $63,201,995$ \\
\hline $\begin{array}{c}\text { Timaya Ft. Sean } \\
\text { Paul }\end{array}$ & Bum Bum & 2014 & $3: 52$ & $50,225,683$ \\
\hline Runtown & Mad Over You & 2016 & $3: 46$ & $66,222,591$ \\
\hline K-Cee ft. Wizkid & Pull Over & 2013 & $3: 35$ & $25,917,337$ \\
\hline $\begin{array}{l}\text { McGalaxy ft. } \\
\text { Davido }\end{array}$ & Nek Unek & 2013 & $3: 49$ & $23,005,127$ \\
\hline $\begin{array}{c}\text { Psquare ft. Don } \\
\text { Jazzy }\end{array}$ & Collabo & 2015 & 4:01 & $56,140,961$ \\
\hline Psquare & $\begin{array}{l}\text { Taste the } \\
\text { Money }\end{array}$ & 2014 & $4: 25$ & $34,969,395$ \\
\hline Mavins Record & Dorobucci & 2014 & 4:41 & $28,244,032$ \\
\hline Korede Bello & Do Like That & 2016 & $3: 55$ & $65,653,996$ \\
\hline Flavour ft Psquare & Sex y Rosey & 2015 & 4:17 & $34,511,485$ \\
\hline Wizkid ft Drake & Come Closer & 2017 & $3: 36$ & $62,000,000$ \\
\hline Davido & Gobe & 2013 & 4:06 & $28,000,000$ \\
\hline
\end{tabular}

Methodology Two -Research on how Sexual objectification of females in Nigerian Pop Music Videos affect females?

This section adopted and adapted the standardized version of the Self-Objectification Questionnaire (SOQ) developed by Noll and Fredrickson (1998) and Later advanced by Fredrickson et al (1998) as a validated and standardized instrument for measuring self-objectification as an aftermath of media's influence on the female gender (Calogero et al, 2005). This scale was developed to help researcher's measure and test the validity of the objectification theory within the context of gender and media studies. The questionnaire originally assesses the level to which individuals perceive their bodies in observable, appearance-based terms versus non-observable, competence based terms without an evaluation of how satisfied they are with their bodies (Calogero et al, 2005). Six attributes concern physical appearance (e.g., physical attractiveness) and six refer to competency (e.g. muscular strength). Scores are obtained by summing ranks for the appearance and competency items and computing the difference between the two categories (Mazzeo \& Karen, 2009)

In the context of this paper, the SOQ's measures were adapted and given Likert Options to ensure individual questions could be measured individually, statistically and summed up individually for Analysis. This approach also became increasingly pertinent to ensure that the diction of the original questionnaire was adapted away from the glorified academic diction with which it was designed into a relatively simple set of questions that can readily be understood by the targeted population. This method was further adopted to ensure transparency and nearness to established survey approaches often deployed in traditional Sociological Surveys.

\section{Sample Size}

A population of 174 females' resident at Goshen Estate Redemption Camp, Ogun State were selected for this study. This population is largely made up of young ladies between the ages of 18-35. The researcher was able to access this population as a result of their membership in a Whatsapp group created for all ladies within the estate for purposes ranging from Sanitation Scheduling, Social Coordination and other key social commitments. The researcher was able to gain the consent of the group through its administrator which made it much easier to receive consent from respondents who further participated in answering the questionnaire.

For the exercise conducted, the sample size of this research (155) was arrived at using the Taro Yamane formula with 95\% confidence level (Yamane, 1967). The calculation is presented as follows; 


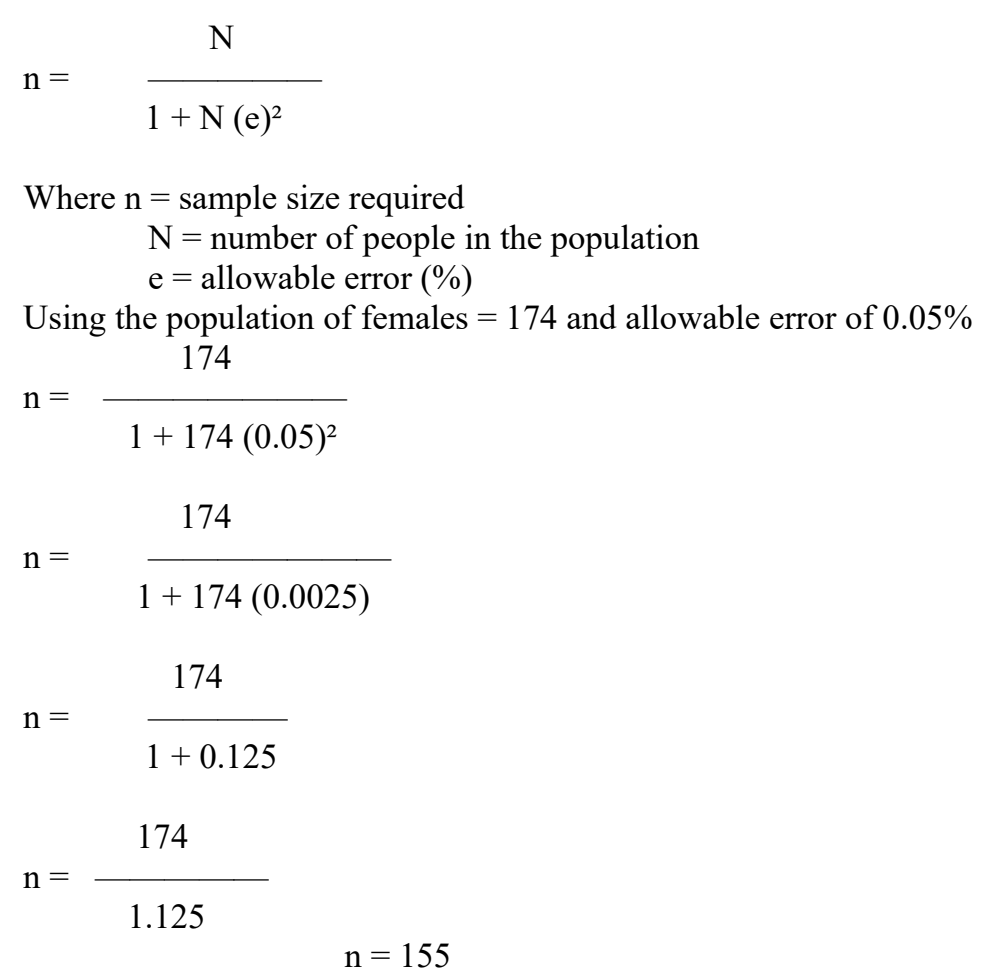

\section{Results}

\section{Part One - Identifying If and How Nigerian Pop Music Sexually Objectify Females}

A Total of 12 videos of varying lengths was coded and analysed. This amounts to a sum total of 49 Minutes and 15 Seconds worth of Music Videos Treated in Time. Out of this 49mins 15 Seconds worth of Music Video Content - 414 Observed Visual Instances of objectification was recorded. Of these 414 instances, 44 instances within 10 of the 12 videos used the camera in a visual manner to dismember (Objectify) the females used in their videos while 21 male gazes/drooling were identified within 8 videos of the 12 analysed.

In the same vein, five core videos of the 12 videos coded consistently used the ladies in their crew as decorative objects or statue and with varying levels of occurrences and emphasis amounting to 22,53,1,7,8 instances. This amounted to 91 times women were used as decorative objects in five videos worth 19 minutes and 3 seconds in time value.

Similarly, four out of the Ten Videos analysed also resorted to conscious body inspection of the female gender with an instance of body shaming. To varying degrees, One video emphasized female body inspection and grading 7 times while a fleeting moment of body inspection by a male gender was captured thirty four (34) times in the second, third and fourth video. Ladies objectified self through self-touch and gaze while seductively dancing 34 times within 7 videos.

Accordingly, Out of the 12 analysed videos, 10 portrayed the female gender's body as the essence of her existence either in slow motion, in full frame or while she laid looking at the sun, camera or caught unawares by the camera. This specific type of objectification occurred 63 times within 10 music videos.

The lyrics are the bedrock of every song. Of the 12 videos analysed, 10 used statements that objectified the female gender was heavily loaded with verbally framed objectification. This amounted to 138 instances cited within varying lines within the lyrics. 
The table below captures the data explicated above.

\begin{tabular}{|c|c|c|c|c|c|c|c|c|c|c|c|}
\hline Artist Name & Song Title & $\begin{array}{l}\text { Year of } \\
\text { Release }\end{array}$ & VL & SO & CF/D & MG/D & $\mathrm{DO} / \mathrm{S}$ & H/BI & SSO & MP & $\mathbf{L Y}$ \\
\hline Davido & If & 2017 & $3: 59$ & 5 & 3 & 1 & - & - & - & 1 & 8 \\
\hline $\begin{array}{l}\text { Timaya Ft. } \\
\text { Sean Paul }\end{array}$ & Bum Bum & 2014 & $3: 52$ & 29 & 8 & 8 & - & - & 2 & 11 & 58 \\
\hline Runtown & $\begin{array}{l}\text { Mad Over } \\
\text { You }\end{array}$ & 2016 & $3: 46$ & 43 & 4 & - & 22 & - & 2 & 15 & 9 \\
\hline $\begin{array}{c}\text { K-Cee ft. } \\
\text { Wizkid }\end{array}$ & Pull Over & 2013 & $3: 35$ & 9 & - & 1 & - & 7 & - & 1 & 10 \\
\hline $\begin{array}{c}\text { McGalaxy ft. } \\
\text { Davido }\end{array}$ & Nek Unek & 2013 & $3: 49$ & 22 & 8 & 6 & - & 1 & 1 & 6 & 5 \\
\hline $\begin{array}{l}\text { Psquare ft. } \\
\text { Don Jazzy }\end{array}$ & Collabo & 2015 & $4: 01$ & 4 & - & 4 & - & - & - & - & 1 \\
\hline Psquare & $\begin{array}{l}\text { Taste the } \\
\text { Money }\end{array}$ & 2014 & $4: 25$ & 56 & 2 & - & 53 & - & - & 1 & - \\
\hline Mavins Record & Dorobucci & 2014 & $4: 41$ & 5 & 4 & - & - & - & - & 1 & - \\
\hline Korede Bello & $\begin{array}{c}\text { Do Like } \\
\text { That }\end{array}$ & 2016 & $3: 55$ & 13 & 4 & 1 & - & - & 4 & 4 & 1 \\
\hline $\begin{array}{l}\text { Flavour } \mathrm{ft} \\
\text { Psquare }\end{array}$ & Sexey Rosey & 2015 & $4: 17$ & 14 & 11 & - & 1 & - & 2 & - & 25 \\
\hline $\begin{array}{ll}\text { Wizkid } & \mathrm{ft} \\
\text { Drake } & \end{array}$ & $\begin{array}{l}\text { Come } \\
\text { Closer }\end{array}$ & 2017 & $3: 36$ & 83 & 17 & 20 & 7 & 12 & 6 & 8 & 13 \\
\hline Davido & Gobe & 2013 & 4:06 & 95 & 16 & 10 & 8 & 21 & 17 & 15 & 8 \\
\hline
\end{tabular}

Key

Artiste Name - Name of the Artiste who owns a song

Song Title - Title of the song owned by a specific artiste

Year of Release - Year within which the song was published

VL - The Normal Video Length or Playback time duration of a Music Video

$\mathrm{S} / \mathrm{O}$ - Instances of Sexual Objectification evident within the duration of a video

$\mathrm{CF} / \mathrm{D}$ - Camera/ framed body dismemberment

MG/D - Male Gaze/Drooling at body part(s)

$\mathrm{DO} / \mathrm{S}$ - Use of Female as decorative objects/statue

H/BI - Harassment/ Body Inspection

SSO - Self-Objectification - Self gaze and or touch while seductively dancing (whining, twerking and other variations of seductive dances).

MP - Portrayal of females in lingerie, bikini or any suggestively nude and revealing attire while dancing.

LY - Lyrics

Part Two - Result displaying data on how Sexual objectification of females in Nigerian Pop Music Videos affects females

Chart 1 shows that out of 155 respondents, 77 respondents representing $49.7 \%$ picked strongly agree, 34 respondents representing $37 \%$ picked Agree, 10 respondents representing $6.5 \%$ picked disagree, 12 respondents representing $7.7 \%$ picked strongly disagree while 22 respondents representing $14.2 \%$ were neutral. This shows that 111 respondents representing $86.7 \%$ were in agreement while 22 respondents representing $14.2 \%$ disagreed.
Chart 1: I often compare how I look with how others look

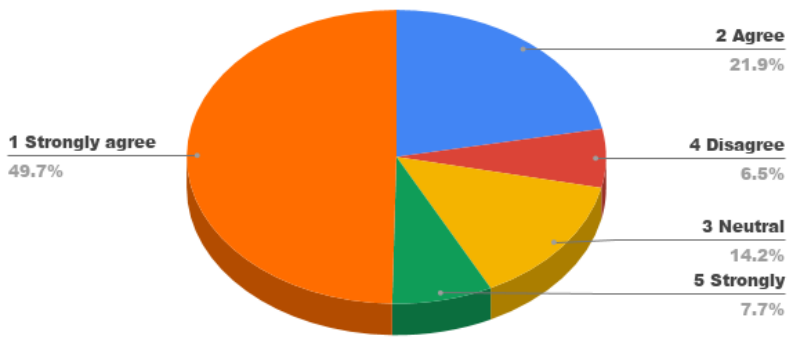


Chart 2 shows that out of 155 respondents, 73 respondents representing $47.1 \%$ picked strongly agree, 37 respondents representing 23.9\% picked Agree, 15 respondents representing 9.7\% picked disagree, 13 respondents representing $8.4 \%$ picked strongly disagree while 17 respondents representing $11 \%$ were neutral. This shows that 110 respondents representing $71 \%$ were in agreement while 28 respondents representing $18.1 \%$ disagreed.

Chart 3 shows that out of 155 respondents, 78 respondents representing $50.3 \%$ picked strongly agree, 34 respondents representing 21.9\% picked Agree, 15 respondents representing 9.7\% picked disagree, 7 respondents representing $4.5 \%$ picked strongly disagree while 21 respondents representing $13.5 \%$ were neutral. This shows that 112 respondents representing $72.2 \%$ were in agreement while 22 respondents representing $14.2 \%$ disagreed.

Chart 4 shows that out of 155 respondents, 70 respondents representing $45.2 \%$ picked strongly agree, 32 respondents representing $20.6 \%$ picked Agree, 23 respondents representing 14.8\% picked disagree, 11 respondents representing $7.1 \%$ picked strongly disagree while 19 respondents representing $12.3 \%$ were neutral. This shows that 102 respondents representing $65.8 \%$ were in agreement while 34 respondents representing $21.9 \%$ disagreed.

Chart 5 shows that out of 155 respondents, 66 respondents representing $42.6 \%$ picked strongly agree, 17 respondents representing 11\% picked Agree, 28 respondents representing 18.1\% picked disagree, 24 respondents representing $15.5 \%$ picked strongly disagree while 20 respondents representing $12.9 \%$ were neutral. This shows that 83 respondents representing $53.6 \%$ were in agreement while 52 respondents representing $33.6 \%$ disagreed.
Chart 2: During the day, I think about how I look many times

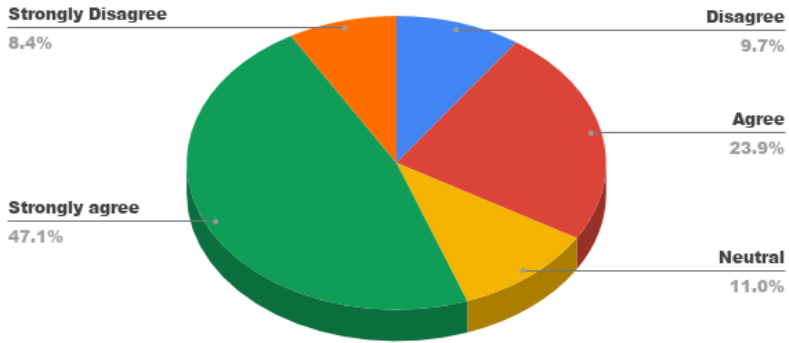

Chart 3: I often worry about how I look to other people

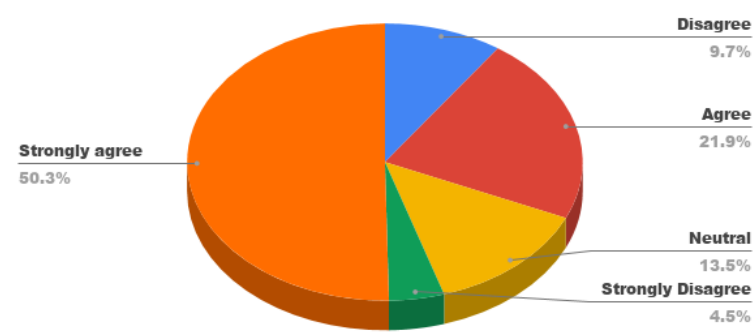

Chart 4: I often worry about whether the clothes I wear make me look sexy

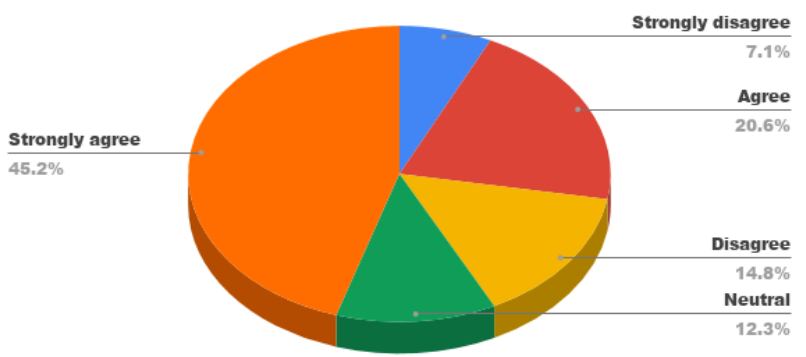

Chart 5: I feel unhappy with myself if I have not made an effort to look sexy and hot

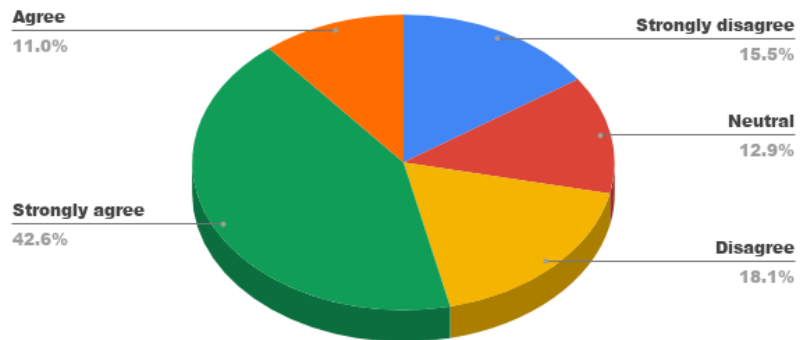


Chart 6 shows that out of 155 respondents, 65 respondents representing $41.9 \%$ picked strongly agree, 19 respondents representing 12.2\% picked Agree, 32 respondents representing $20.6 \%$ picked disagree, 32 respondents representing $20.6 \%$ picked strongly disagree while 7 respondents representing $4.5 \%$ were neutral. This shows that 84 respondents representing $54.1 \%$ were in agreement while 64 respondents representing $41.2 \%$ disagreed.

Chart 7 shows that out of 155 respondents, 65 respondents representing $41.9 \%$ picked strongly agree, 24 respondents representing 15.5\% picked Agree, 24 respondents representing 15.5\% picked disagree, 32 respondents representing $20.6 \%$ picked strongly disagree while 10 respondents representing $6.5 \%$ were neutral. This shows that 89 respondents representing $57.4 \%$ were in agreement while 56 respondents representing $36.1 \%$ disagreed.

Chart 8 shows that out of 155 respondents, 66 respondents representing $42.6 \%$ picked strongly agree, 23 respondents representing 14.8\% picked Agree, 22 respondents representing $14.2 \%$ picked disagree, 36 respondents representing $23.2 \%$ picked strongly disagree while 8respondents representing 5.2\% were neutral. This shows that 89 respondents representing $57.4 \%$ were in agreement while 58 respondents representing $37.4 \%$ disagreed.

Chart 9 shows that out of 155 respondents, 75 respondents representing $48.4 \%$ picked strongly agree, 33 respondents representing 21.3\% picked Agree, 14 respondents representing $9 \%$ picked disagree, 17 respondents representing $11 \%$ picked strongly disagree while 16 respondents representing $10.3 \%$ were neutral. This shows that 108 respondents representing 69.7\% were in agreement while 31 respondents representing $20 \%$ disagreed.

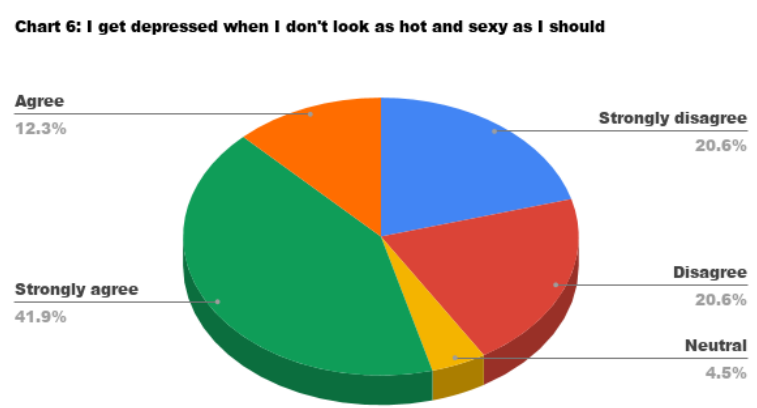

Chart 7: I would be unhappy if people knew what I really weigh

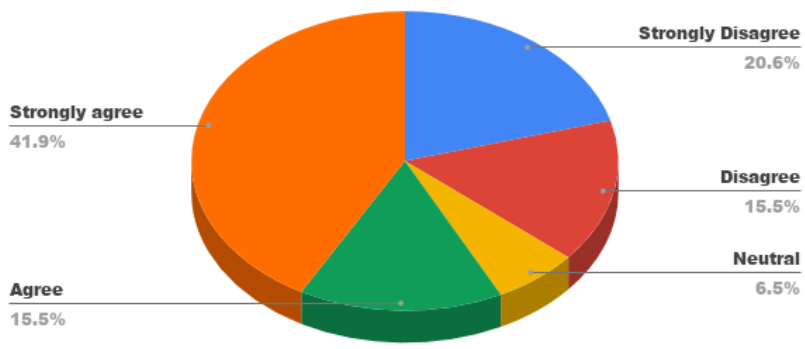

Chart 8: When I'm not exercising enough, I question whether I'm a good person

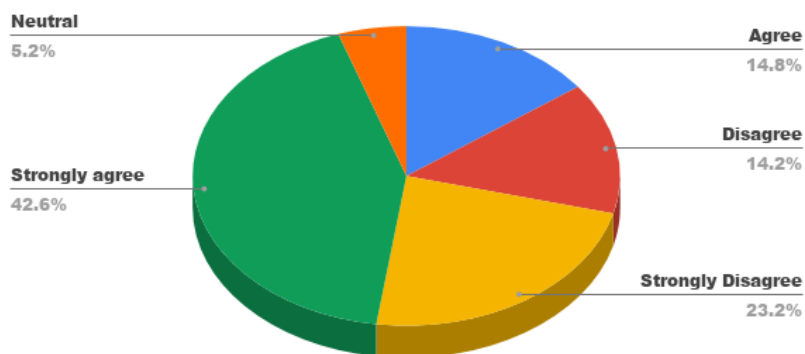

Chart 9: I feel unhappy when I'm not the size I think I should be

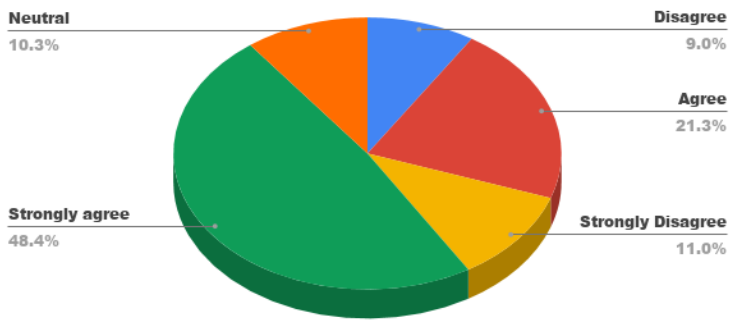


Chart 10 shows that out of 155 respondents, 67 respondents representing $43.2 \%$ picked strongly agree, 21 respondents representing 13.5\% picked Agree, 20 respondents representing $12.9 \%$ picked disagree, 32 respondents representing $20.6 \%$ picked strongly disagree while 15 respondents representing $9.7 \%$ were neutral. This shows that 88 respondents representing $56.7 \%$ were in agreement while 52 respondents representing $33.5 \%$ disagreed.

Chart 10: I feel useless at times

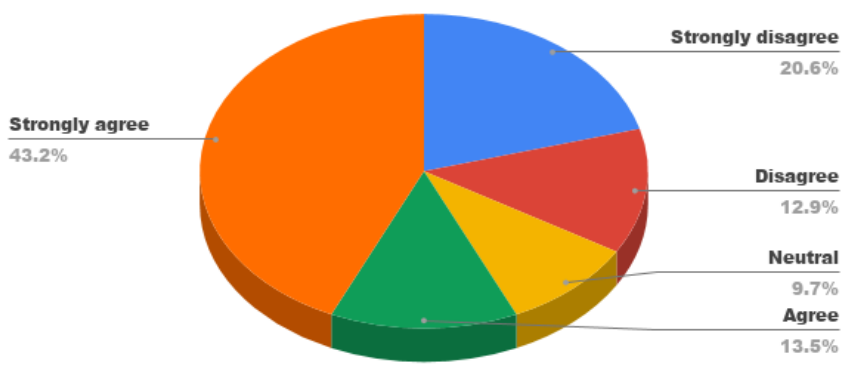

Chart 11: I am dietin

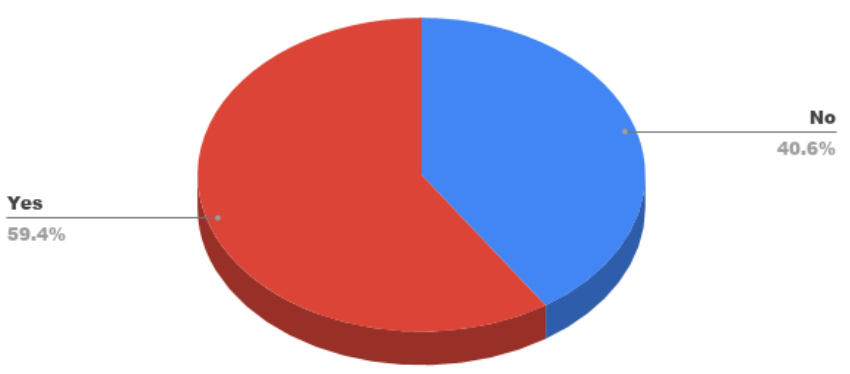

Chart 11 shows that out of 155 respondents, 92 respondents representing 59.4\% picked Yes when asked if they were dieting while 63 representing $40.6 \%$ picked No.

Chart 12 shows that out of 155 respondents, 154 respondents representing 99.4\% picked Female when asked of their gender while 1 representing $0.6 \%$ picked Male.

Chart 12: I am female

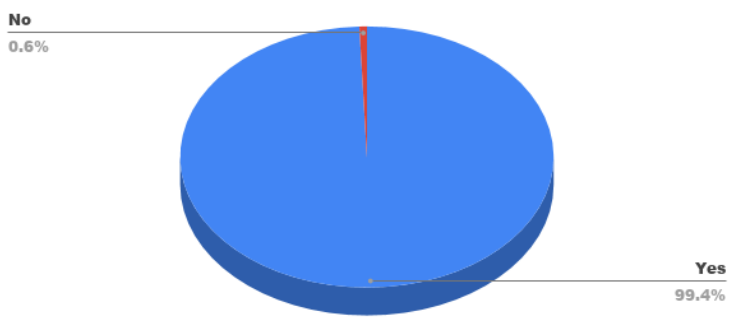

Chart 13 shows that out of 155 respondents, 77 respondents representing $49.7 \%$ picked strongly agree, 35 respondents representing $22.6 \%$ picked Agree, 11 respondents representing 7.1\% picked disagree, 6 respondents representing $3.7 \%$ picked strongly disagree while 26 respondents representing $16.8 \%$ were neutral. This shows that 112 respondents representing $72.3 \%$ were in agreement while 17 respondents representing $10.8 \%$ disagreed.
Chart 13: I watch a lot of pop contemporary Nigerian Music Videos

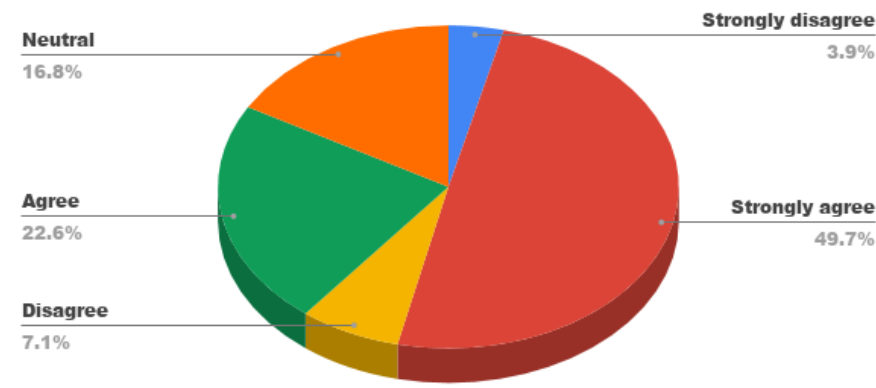


Chart 14 shows that out of 155 respondents, 76 respondents representing $49 \%$ picked strongly agree, 28 respondents representing $18.1 \%$ picked Agree, 17 respondents representing $11 \%$ picked disagree, 15 respondents representing $9.7 \%$ picked strongly disagree while 19 respondents representing $12.3 \%$ were neutral. This shows that 104 respondents representing 67.1\% were in agreement while 32 respondents representing $20.7 \%$ disagreed.

Chart 15 shows that out of 155 respondents, 68 respondents representing $43.9 \%$ picked strongly agree, 20 respondents representing 12.9\% picked Agree, 15 respondents representing $9.7 \%$ picked disagree, 42 respondents representing $47.1 \%$ picked strongly disagree while 10 respondents representing $6.5 \%$ were neutral. This shows that 88 respondents representing $56.8 \%$ were in agreement while 57 respondents representing $56.8 \%$ disagreed.

Chart 16 shows that out of 155 respondents, 69 respondents representing $44.5 \%$ picked strongly agree, 25 respondents representing $16.1 \%$ picked Agree, 17 respondents representing 11\% picked disagree, 35 respondents representing $22.6 \%$ picked strongly disagree while 9 respondents representing $5.8 \%$ were neutral. This shows that 94 respondents representing $60.6 \%$ were in agreement while 52 respondents representing $33.6 \%$ disagreed.

Chart 17 shows that out of 155 respondents, 64 respondents representing $41.3 \%$ picked strongly agree, 26 respondents representing $16.8 \%$ picked Agree, 24 respondents representing $15.5 \%$ picked disagree, 32 respondents representing $20.6 \%$ picked strongly disagree while 9 respondents representing $5.8 \%$ were neutral. This shows that 90 respondents representing $58.1 \%$ were in agreement while 56 respondents representing $36.1 \%$ disagreed.
Chart 14: I desire to have slim and curvy figure 8 body shape like the models or video vixens on Wizkid's Music Videos

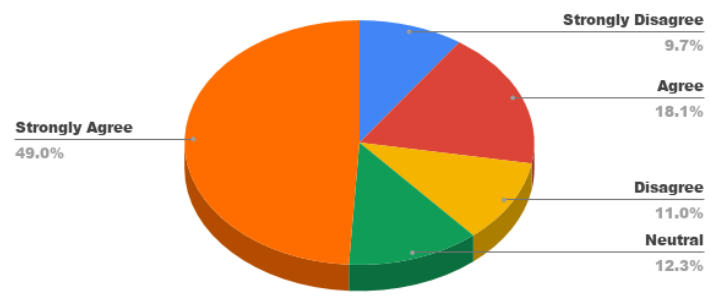

Chert 15: I crave to be as sexy as girls on Timaya's Music videos that's why I diet or take slimming tea

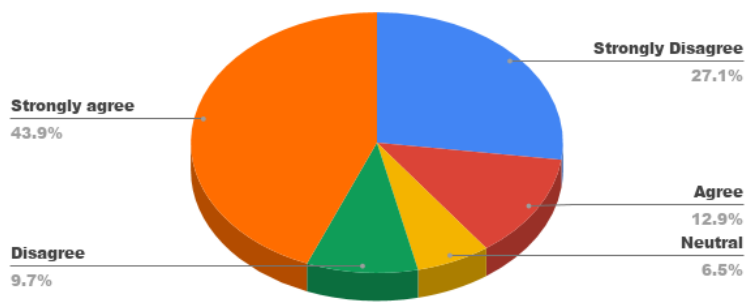

Chart 16: I would conveniently slay with a bum short and bikini top anywhere to flaunt my beauty

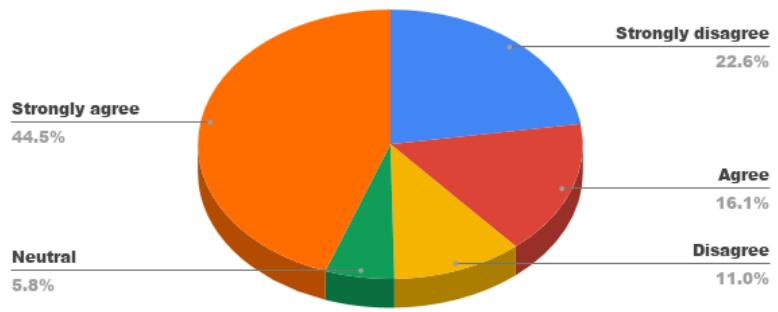

Chart 17: I am usually jealous of slim figure 8 gir

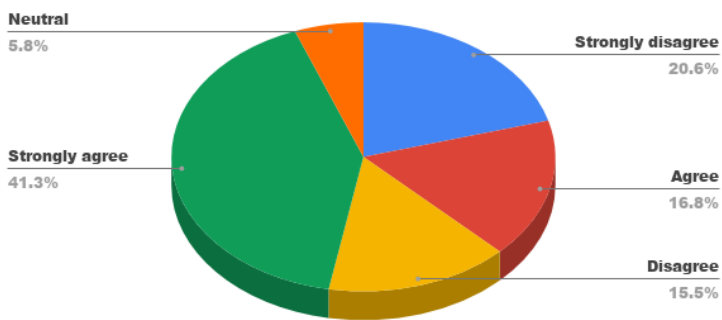


Chart 18 shows that out of 155 respondents, 65 respondents representing $41.9 \%$ picked strongly agree, 17 respondents representing $11 \%$ picked Agree, 18 respondents representing $11.6 \%$ picked disagree, 43 respondents representing $27.7 \%$ picked strongly disagree while 11 respondents representing $7.1 \%$ were neutral. In the others area, a respondent stated "Aint got time for that bullshit" representing $0.7 \%$. This shows that 82 respondents representing $52.9 \%$ were in agreement while 61 respondents representing $39.3 \%$ disagreed.
Chart 18: I get depressed after watching girls with nice body shapes on contemporary pop Nigerian Music Videos

Aint got time for

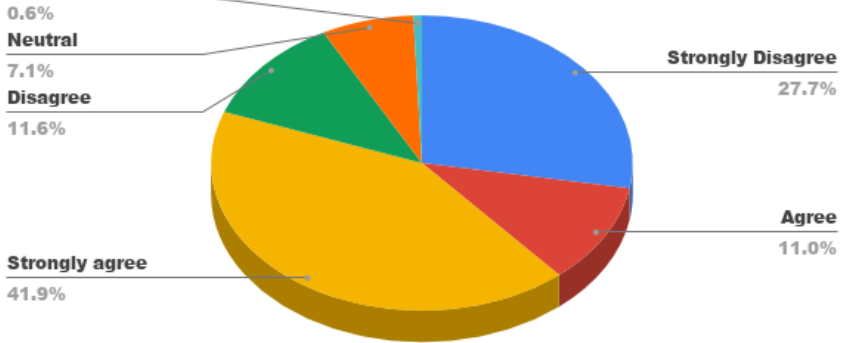

Chart 19 shows that out of 155 respondents, 64 respondents representing $41.3 \%$ picked strongly agree, 20 respondents representing 12.9\% picked Agree, 26 respondents representing $16.8 \%$ picked disagree, 37 respondents representing $23.9 \%$ picked strongly disagree while 8 respondents representing 5.2\% were neutral. This shows that 84 respondents representing $54.2 \%$ were in agreement while 63 respondents representing $40.7 \%$ disagreed.

Chart 20 shows that out of 155 respondents, 64 respondents representing $41.3 \%$ picked strongly agree, 17 respondents representing $11 \%$ picked Agree, 27 respondents representing 17.4\% picked disagree, 42 respondents representing $27.1 \%$ picked strongly disagree while 5 respondents representing $3.2 \%$ were neutral. This shows that 81 respondents representing $52.3 \%$ were in agreement while 69 respondents representing $44.5 \%$ disagreed.

Chart 21 shows that out of 155 respondents, 61 respondents representing $39.4 \%$ picked strongly agree, 20 respondents representing $12.9 \%$ picked Agree, 15 respondents representing 9.7\% picked disagree, 55 respondents representing $35.5 \%$ picked strongly disagree while 3 respondents representing $1.9 \%$ were neutral. In the others area, a respondent stated "nobody is that dense" representing $0.6 \%$. This shows that 81 respondents representing $52.3 \%$ were in agreement while 70 respondents representing $45.2 \%$ disagreed.

\section{Chart 19: I have been working out seriously to look}

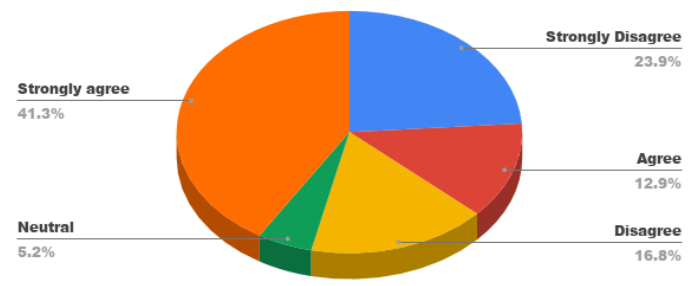

Chart 20: I buy wears similar to those sexy ones on Trending Pop Nigerian Music Videos

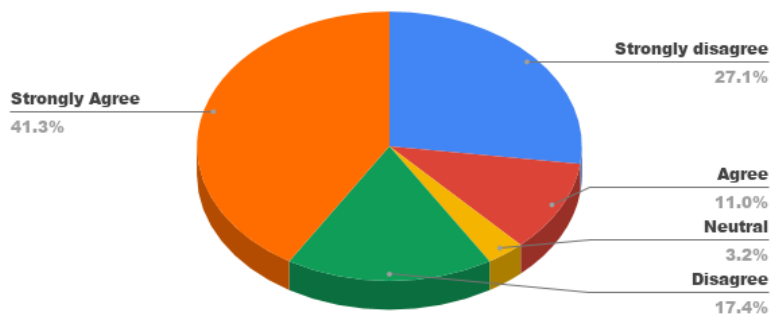

Chart 21: I take Slimming tea or pills to be slim and curvy like a particular celebrity or model

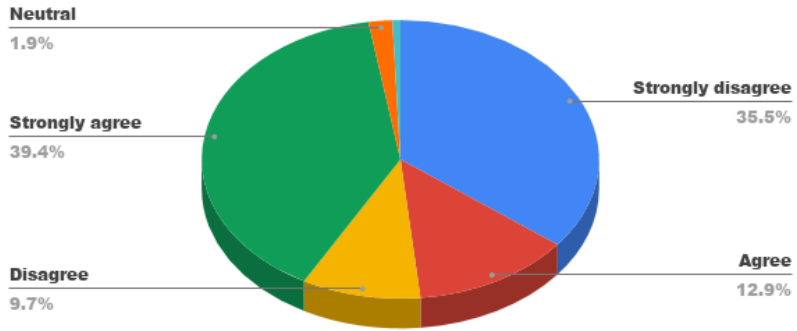


Chart 22 shows that out of 155 respondents, 73 respondents representing $47.1 \%$ picked strongly agree, 32 respondents representing $20.6 \%$ picked Agree, 18 respondents representing 11.6\% picked disagree, 17 respondents representing $11 \%$ picked strongly disagree while 15 respondents representing $9.7 \%$ were neutral. This shows that 105 respondents representing $67.7 \%$ were in agreement while 35 respondents representing $22.6 \%$ disagreed.

Chart 23 shows that out of 155 respondents, 58 respondents representing $37.4 \%$ picked strongly agree, 17 respondents representing $11 \%$ picked Agree, 14 respondents representing 9\% picked disagree, 64 respondents representing $41.3 \%$ picked strongly disagree while 2 respondents representing $1.3 \%$ were neutral. This shows that 75 respondents representing $48.4 \%$ were in agreement while 78 respondents representing 50.3\% disagreed.

Chart 24 shows that out of 155 respondents, 68 respondents representing $43.9 \%$ picked strongly agree, 23 respondents representing 14.8\% picked Agree, 13 respondents representing 8.4\% picked disagree, 29 respondents representing $18.7 \%$ picked strongly disagree while 20 respondents representing $12.9 \%$ were neutral. In the others area, 2 respondents stated the following

1. "Depends on who the man is"

2. "I get irritated when a man does that ".

Both represent $1.3 \%$ and this shows that 91 respondents representing $58.7 \%$ were in agreement while 42 respondents representing $27.1 \%$ disagreed. Chart 25 shows that out of 155 respondents, 70 respondents representing $45.2 \%$ picked strongly agree, 26 respondents representing 16.8\% picked Agree, 21 respondents representing $13.5 \%$ picked disagree, 34 respondents representing $21.9 \%$ picked strongly disagree while 4 respondents representing $2.6 \%$ were neutral. This shows that 96 respondents representing $62 \%$ were in agreement while 47 respondents representing $35.4 \%$ disagreed.

Chart 26 shows that out of 155 respondents, 61 respondents representing $39.4 \%$ picked strongly agree, 14respondents representing 9\% picked Agree, 25 respondents representing $16.1 \%$ picked disagree, 50 respondents representing $32.3 \%$ picked strongly disagree while 5 respondents representing 3.2\% were neutral. This shows that 71 respondents representing $48.4 \%$ were in agreement while 75 respondents representing $48.4 \%$ disagreed.
Chart 22: I love it when a man drools over my body and commends it

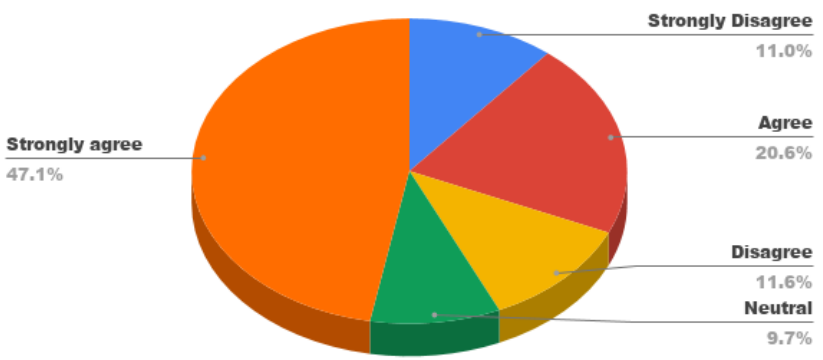

Chart 23: I use whitening or bleaching cream to lighten my skin to be sexy and attractive like some of the models on Nigerian Music videos

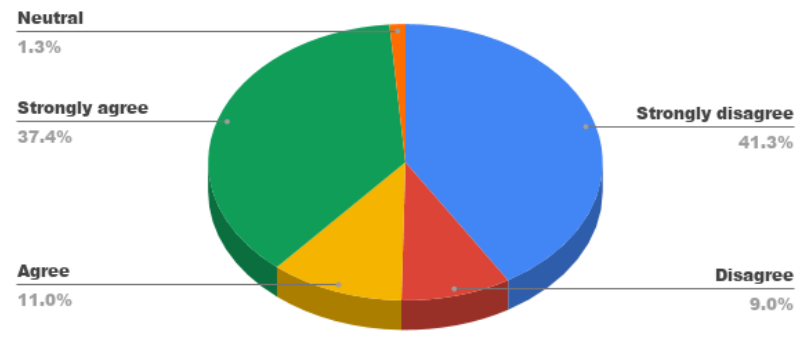

Chart 24: I love it when a man admires and commends my body shape, breasts and buttocks

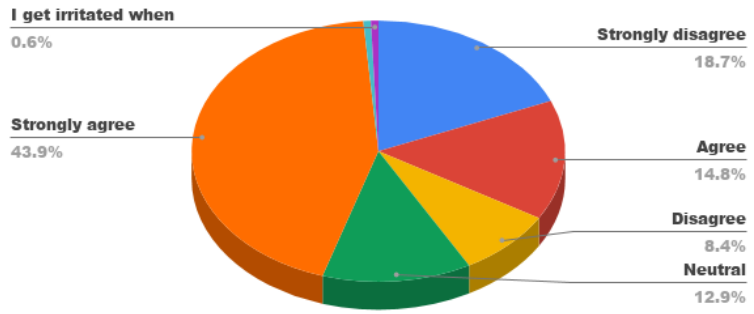

Chart 25: I don't eat as normal and as regular as I should because I want to stay slim, fit and attractive

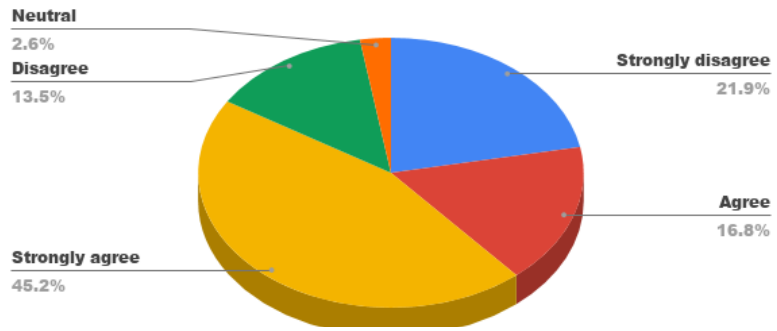

Chart 26: I often feel ashamed and destabilized when I go out without make up

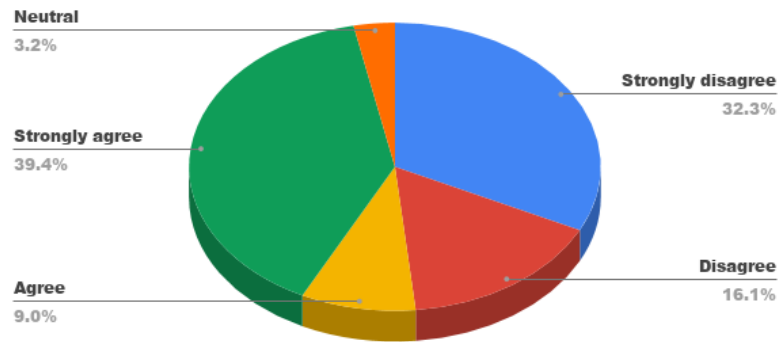




\section{Discussion}

The results displayed above offer empirical prove that Nigeria Pop Entertainment Media and specifically its pop music video sector objectify the female gender in framing meaning. The columns after instances of objectification are detailed as to how in each video the female gender was objectified and to what intensity. This as a sample study does reflect the population of pop music videos even though there may be exceptions as regards genres. More research could be conducted into trends in objectification within genres through time and advancement in technology. Furthermore, while it is true that objectification remains objectification in its entirety, irrespective of forms it assumes, it is important that one notes the varying forms for policy creation or amendment purposes. Furthermore, it may be interesting however to observe that as opposed to other variations of sexual objectification of the female gender, it does appear as though the columns on camera framing/ dismemberment and that of sexual portrayals appeared more populated compared to the columns displaying male gazes/drooling, use of the female gender as decorative object, body inspection/harassment and selfobjectification. This observation is strikingly important because it appears as though the cinematographers and the directors may have been trying to communicate certain messages as implied by the framing theory. Furthermore, although the researcher did not code for portrayals of media constructed and projected stereotype of the ideal female body shape (hour glass shape, Barbie shaped), in coding for instances of objectification within these music videos, the researcher did observe that almost all coded instances of female objectification, captured the use of females with the ideal and Eurocentric definition of the perfect body shape. The only exception occurred where body shaming was observed in an instance of body inspection - i.e. K.C - Pullover $2: 28$ s. This observation is relevant because these portrayals do not neutrally reflect varying degrees of body type realities.

While all forms of objectification impacts the psychology and behaviours of individuals (Fredrickson and Roberts, 1997) and negatively impacts the female gender as studies have shown (Moradi and Huang, 2008), the current state and intensity in frequency of female objectification and poor portrayal of the female gender as coded in a single video and with relation to the fact that $100 \%$ of the research sample returned positive for varying degrees of objectification and other gender sensitive issues further strengthens the argument that Audio visual contents ( especially Pop Nigerian Music videos) Objectifies women.

Complementing the findings on the evidence that Nigerian pop music videos objectify females is the results of the research done on the impact of sexual objectification as seen on Nigerian pop music videos on some females in Nigeria. A critical observation of answers to some key questions reveal that a majority of females who participated in the survey have been negatively and deeply impacted by the images and probably sound of objectification often portrayed by most Nigerian pop music videos. So, while most questions targeted at assessing seemingly lighter self-objectification instances came in positive (questions such as - I love it when a man admires and commends my shape, breasts and buttocks); others that focused on the crux of the issue which is to assess the damaging side of self-objectification on Nigerian females i.e. see if Sexual Objectification in Pop Nigerian Music videos had a negative impact on Nigerian females, dragged in some interesting findings. For instance the following set of questions and their responses reflected the extent of effect these videos have on behaviors and beliefs of some Nigerian females.

1. Question 14: I desire to have slim and curvy figure 8 body shape like the models or video vixens on Wizkid's Music Videos.

Responses: Strongly Agree: 79 (49\%); Agree: 28 (18.1\%); Neutral: 19 (12.3\%); Disagree: 17 (11\%); Strongly Disagree: $15(97 \%)$

2. Question 15: I crave to be as sexy as girls on Timaya's Music videos that's why I diet or take slimming tea.

Responses: Strongly Agree: 68 (43.9\%); Agree: 20 (12.9\%); Neutral: 10 (6.5\%); Disagree: 15 (9.7\%); Strongly Disagree: $42(27.1 \%)$

3. Question 18: I get depressed after watching girls slay with nice body shapes on contemporary pop Nigerian Music Videos

Responses: Strongly Agree: 65 (41.9\%); Agree: 17 (11\%); Neutral: 11 (7.1\%); Disagree: 18 (11.6\%); Strongly Disagree: $43(27.7 \%)$

4. Question 19: I have been working out seriously to look slim curvy and sexy like the girls on Music Videos

Responses: Strongly Agree: 64 (41.3\%); Agree: 17 (11\%); Neutral: 5 (3.2\%); Disagree: 27 (17.4\%); Strongly Disagree: $42(27.1 \%)$

5. Question 20: I have been buying some wears similar to those sexy ones on trending pop Nigerian Music Videos

Responses: Strongly Agree: 64 (41.3\%); Agree: 28 (18.1\%); Neutral: 19 (12.3\%); Disagree: 17 (11\%); Strongly Disagree: $15(97 \%)$ 
6. Question 21: I take slimming tea or pills to be slim and curvy like a particular celebrity or model Responses: Strongly Agree: 61 (39.4\%); Agree: 20 (12.9\%); Neutral: 3 (1.9\%); Disagree: 15 (9.7\%); Strongly Disagree: $55(35.5 \%)$

7. I use whitening or bleaching cream to lighten my skin to be sexy and attractive like some of the models on Nigerian Music Videos

Responses: Strongly Agree: 58 (37.4\%); Agree: 17 (11\%); Neutral: 2 (1.3\%); Disagree: 14 (9\%); Strongly Disagree: $64(41.3 \%)$.

Consequently, these results reflect the perspective that sexual objectification of the female gender in Nigerian Pop Music videos does negatively affect the behaviour and belief of females in Nigeria as they in turn self-objectify as evident in the findings of this research work. The findings of this paper thus support the postulations of the objectification theory as its findings affirm the position of the objectification theory.

While findings of this research backs concrete postulations of the framing and objectifications theories, realistically, this sector could use the attention of some ethical quarters and media content regulatory bodies in managing and eradicating demeaning and gender sensitive details even as it relates to the portrayals and objectification of the female gender. In managing and regulating content, it may be beneficial if the focus is considerably removed from attempting to rescue the audience (especially Nigerian females) from obscene or unworthy content through bans and slams of NTBB (Not to be broadcast) labels on music videos as is the current trend with the Nigerian Broadcasting Commission. This is important because as opposed to earlier times where a ban on a music video meant the end of the content, in the times we find today's media, one can easily meander this national media censorship boards and restriction funnels through to accessing audiences online and publishing content(as it has been the case) - because the new information age functions to democratize media and create a power struggle for means of media production, distribution and consumption (Castells, 2007; 2010) i.e. empowering everyone with a mobile gadget and an internet connection to access, broadcast and share content to an even greater and wider audience compared to the prowess and reach of most national mass media establishments. This in essence enables content providers within national jurisdictions to boycott instituted media channels, organograms or bureaucratic bottlenecks.

To this extent and at the risk of steering the wrong direction, the focus could be channelled towards mitigating and finally eradicating these anomalies in Nigerian pop music videos whilst ensuring that a proper national image is maintained through exercising control and regulation over content and the processes involved in content creation for screen media. In essence, exerting control over how music titles are framed and how females are portrayed or presented in each instance of a music video. This feat can be achieved through sensitizing media professionals such as the director, producer, cinematographer, artistes, make-up artiste and other professionals involved in spurning music video contents on the ethics, guidelines, laws and policies to be followed while operating as a media professional within Nigerian Jurisdictions. To further aid enforcement, a license system may be adopted where licenses for professional practice may be granted and revoked as the case may be. This could further ensure that professionals live by the ethics, laws and code of conduct of their profession while adhering to ramifications also specific to gender sensitive issues and that of female objectification seeing that it affects the population and Nigerian females specifically.

To further exert an even stronger authority, a coalition or affiliated bond and agreement between Nigeria's media content regulatory bodies and popular online social media platforms and video content management systems such as Youtube, Veevo, Facebook, Twitter, Instagram etc. - to block or ban content with certain negative portrayals coming from the Nigerian sphere of entertainers could further strengthen the authority and relevance of our regulatory boards and promote conformity to demands placed upon content by a national media regulatory body which is in itself a social institution.

Interestingly, media and its regulatory body as established social institutions possess the key to fixing negative perceptions about the female gender as proposed by Mali and Patankar's (2015). The optimistic stance on media's ability to correct these misconceptions about the female gender is sustained in this paper as it has been proven through media and communication theories and studies that media possesses power to influence the masses and reconstruct preconceived notions towards a more positive orientation. Theories such as the Agenda settings theory, cultivation theory, hypodermic needle theory, modelling theory and practical instances of the use of Sabido Methodology in reconstructing society through media suffice as proof that branches of media can effect positive changes in relation to managing and catalysing a more positive image reception of the female gender. But again, this change could begin with the content creators and those who frame meaning in an attempt to interpret a music video concept.

\section{Conclusion and Recommendations}

Nigeria's entertainment media may be attempting to sustain primordial patriarchal cultural practices that perceived the female gender as second level humans or adapting to global trends as media imperialist theories have explicated. But then, while these seems to be the case, a careful consideration as to the effect on the female 
gender as a human and a person with existential needs and ability to function and create value away from her body, requires society and media's awareness as it implies taking measures towards redressing steps hitherto taken to negatively portray and stereotype the female gender. In adopting correctional measures to properly portray and represent the female gender in media, the female gender's image as a person would have been reinstated. Gender sensitive issues in Music Videos may need to be properly designed and crafted by the artiste, director and crew while taking into consideration the required needs for proper portrayals. The case of proper framing of content using the professional tools at his disposal e.g. diction and lyrics, correction, proper costumes, proper blocking and manner of presentation, soft wares, place and background of shoot and even symbols may aid the director's conceptualization process in the proper interpretation of the music video script on screen. Going forward, to solidly concretize the policies against poor portrayal of the female gender either in music videos or in any entertainment medium within Nigeria, laws and enforcement of these laws may be required as supporting frameworks to keep media and performing practitioners in check as regards issues surrounding female objectification and poor and even stereotypical portrayals of the female gender.

In tackling observed variations as to the objectification of women, these recommendations may aid a proper representation of the female gender within music videos and the entertainment media in extension.

Variation 1 - Camera/ framed body dismemberment.

This type of objectification which is known to dehumanize the female gender through conscious focus on specific sexually perceived body parts can be mitigated through the enactment of a regulatory body with sets of policies and rules properly managed to grant and revoke practice licences to/from cinematographers/videographers who default on professional and ethical guidelines guarding against female objectification and other laws within the Entertainment industry. This approach basically revokes the operational license hitherto granted any defaulter to operate within Nigeria.

Variation 2 - Male Gaze and Drooling at female body or body part(s)

This form of objectification although difficult to regulate as it maintains a thin line between simple and harmless gaze and admiration, can be regulated and managed if observed instances are not captured and framed by the media. Furthermore, it may be rewarding to rebuke colleagues where awareness and self-restrain is not observed. In this instance, the believe is that where and when a male gender is not conversing with a female gender, his eye movement will either be fixed on something of interest or fleeting and randomly engaged in his environment. Where one is fixated on a certain being and probably a female's body part for more than a moment, objectification may have ensued. Here, a pat on the back, rebuke or some humane form of correctional measure may be required.

\section{Variation 3 - Use of Female as decorative objects/statue}

This form of objectification dehumanizes the female gender and reduces her to the status of an item needed for decoration. In Music Video creation, the costumier, make-up artiste, choreographer, scenery designer and the director could kick against the use of any model along this line. Policies and laws prohibiting the use of stationed females may be required to spark awareness as well as adherence in this regard.

\section{Variation 4 - Body Inspection/ Harassment}

An instance of Body inspection is often established through conscious effort to see and probably grade all features of the female body or her parts. In some cases such as the ones observed in some of the analysed music videos, the male inspector orders the lady to rotate while he observes and nods to express like or dislike at what he sees. In other instances, violence may be involved. There is a need for sensitization in this regard as it has become the norm and can easily pass for admiration. Where individuals are aware of this through the use of media to establish different forms of orientation, societies would have purged self of this form of objectification.

Variation 5 - Self-Objectification - Self gaze and/or touch while seductively dancing (whining, twerking and other variations of seductive dances)

Self-Objectification is often blamed on media and social influence and pressure on the female gender's body and body part but if one ponders on the weight of this view, it does appear as though the female in focus has no choice and is in fact defenceless. To some extent this may be true and to certain extent this is false. At the risk of taking away from social pressures on the female gender, the crux of the issue may be that females are unaware of what they do to their gender in music videos. From this perspective, where an individual is enlightened; she tends to know rights from wrongs. This awareness and orientation may aid females in music videos ascertain their indulgence during content creation while clearly stating what they can and will do and what they will not do in a music video to aid the cause for proper female portrayals In media. As with other variations, laws may be required to support females who may be victimized or discriminated against for taking a strong stand for the cause of the female gender.

Variation 6 - Portrayal of figure 8 and Barbie shaped girls in lingerie, bikini or any suggestively nude and revealing attire while dancing.

The way she dresses will be the way she is addressed. To help the case of female exploitation in media as it relates to objectification and negative portrayals of women in Nigerian entertainment media, video vixens or 
dancers contracted to function in the making of visual media content may need to assertively propose wears that are decent. In line with this perspective, erotic, promiscuous and sexually provocative dance moves often proposed by choreographers may require reconstruction towards an ideal and decent dance. To further spice up the video content, other females with different body types and configurations may be contracted to feature on video contents as the case may be. This is to ensure that all female body types are properly represented on air. To aid strict adherence to these proposal, laws and policies may be required as support framework to aid conformity.

Similarly, the cinematographer, the artiste and the director may need to put in a bit more work in finding interpretative meanings to the female gender away from her body. By doing this, the audience's attention is consciously removed from focus on objectifying the body of the female gender towards seeing value in what she offers society.

\section{Variation 7 - Lyrics}

Here lies the base moment of creativity where cognition goes to work, churning out experiences and what the mind perceives to be entertaining. Here, the artiste may seek inspiration away from the female body. Where the focus of inspiration is on the female, the attention could then revolve around the female person and the values she offers as opposed to focus on the body and body parts. Interestingly life offers a lot of beautiful things and values to mash into creative pieces. To help the case of objectification of the female gender in lyrics, sexually suggestive and masked lyrics may not be required in writing lyrics as it will inevitably require interpretation and demonstration when the music video is in the making.

\section{References}

Balraj, B. (2015). Understanding Objectification Theory. International Journal on Studies in English Language and Literature (IJSELL) Volume 3, Issue II, November 2015 pp70-74 ISSN 2347-3126 (Print) and ISSN 2347-3134 (Online) www.arcjournals.org (Accessed 4th April 2018)

Barber, J. (2011). Media and Change: Objectification of Women in Entertainment Media. Available at https://sites.google.com/a/uw.edu/media-and-change/content/objectification-of-women-in-media (Accessed 3rd April 2018)

Brown, J. (2010). Mass media influences on sexuality. The Journal of Sex Research, 39:1, 42-45, DOI: $10.1080 / 00224490209552118$

BuzzNigeria. (2018). 30 Most Popular Nigerian Music Videos on Youtube. Available at https://buzznigeria.com/nigerian-music-videos/ (Accessed 10th April 2018)

Calogero, R., Davies, W., Thompson, K. (2005) The Role of Self-Objectification in the Experience of Women with Eating Disorders. Sex Roles, Vol. 52 Nos. 1 /2. DOI:10.1007/s11199-005-1192-9

Calogero, R. (2012). Objectification Theory, self-objectification, and body image. In: Cash, Thomas, (ed.) Encyclopaedia of Body Image and Human Appearance. Academic Press, pp. 574-580. ISBN 9780123849250

Castells, M. (2007). Communication, Power and Counter-Power in the Network Society. International Journal of Communication. Vol. 1 pp238-266. Available at http://ijoc.org (Accessed 20th May 2017).

Castells, M. (2010). The Rise of the Network Society. Oxford: Blackwell Publishing Ltd.

Chambers, D., Steiner, L. \& Fleming, C. (2004). Women and Journalism. London: Routledge.

Chong, D. \& Druckman, J. (2007). A Theory of Framing and Opinion Formation in Competitive Elite Environments. Journal of Communication 57 (2007) 99-118. International Communication Association.

Definedterm (N.D.) Gender-Sensitivity. Available at: https://definedterm.com/a/definition/206900 (Accessed 4th April 2018)

Ekwueme, L. (2004) Essays on African and African-American music and culture, Lagos:LENAUS.

Espinosa, D. (2010). Gender roles in the media and debunking society's stereotypes: Glee as a pop-culture reflection. Available at https://www.winona.edu/counseloreducation/images/Danya_Espinosa_Capstone.pdf (Accessed 6th April 2018)

Fredrickson, B \& Roberts, T (1997). Objectification Theory: Toward Understanding Women's Lived Experiences and Mental Health Risks. Psychology of Women Quarterly. Available at journals.Sagepub.com/doi/abs/10.1111/j.1471-6402.1997.tb00108.x?journalCode=pwqa (Accessed 4th April 2018)

Gaunlet, D. (2008). Media, Gender and Identity: An Introduction (2nd Edition). New York: Routledge.

Goffman, E. (1974). Frame Analysis: An Essay on the Organization of Experience. New York: Harper and Row.

Gruber, E. \& Grube J. (2000). Adolescent sexuality and the media - a review of current knowledge and implications. Available at: https://www.ncbi.nlm.nih.gov/pmc/articles/PMC1070813/ (Accessed 2nd April 2018)

Kirk, M. (2009). Mass Media as Social Institution: The Wired Example. Gender and Information Technology: Moving Beyond Access to Co-Create Global Partnership. p.34 DOI: 10.4018/978-1-59904-786-7.ch004 
Kwaramba, A. \& Morna, C. (2003). Gender and Media Baseline Study, Tanzania Report. Johannesburg: Media Institute of Southern Africa (MISA) and GenderLinks (GL). Available at genderlinks.org.za/what-wedo/media/research/gender-and-media-baseline-study/ (Accessed 4th April 2018)

Lantagne, A. (2014). Gender Roles in Media. Available at https://www.huffingtonpost.com/allisonlantagne/gender-roles-media b 5326199.html (Accessed 2nd April 2018)

Lindner, D., Tantleff-Dunn, S. (2017). The Development and Psychometric Evaluation of the SelfObjectification Beliefs and Behaviors Scale. Psychology of Women Quarterly Vol 41, Issue 2, pp. 254 272. Available at: https://doi.org/10.1177/0361684317692109 (Accessed 15th August, 2018)

Littlejohn, S. \& Foss, K. (2009). Encyclopaedia of Communication Theory. London, Sage Publications, Inc.

Mali, N. \& Patankar, P. (2015). Role of Media In Prohibition Of Gender Discrimination. Research Front. I. 5156. Available https://www.researchgate.net/publication/286156021_ROLE_OF_MEDIA_IN_PROHIBITION_OF_GEN DER DISCRIMINATION (Accessed 3rd April 2018).

Mazzeo, S. and Karen, S. (2009) Evaluation of Structural Model of Objectification Theory and Eating Disorder Symptomatology among European American and African American Undergraduate Women. Psychology of Women Quarterly. Available at: www.ncbi.nlm.nih.gov/pmc/articles/PMC2835368/ (Accessed 15th August, 2018)

Miles-McLean, H., Liss, M., Erchull, M. J., Robertson, C. M., Hagerman, C., Gnoleba, M. A., \& Papp, L. J. (2015). "Stop looking at me!" Interpersonal sexual objectification as a source of insidious trauma. Psychology of Women Quarterly, 39(3), 363-374.

Moradi, B. \& Huang, Y. (2008). Objectification Theory and Psychology of Women: A Decade of Advances and Future Directions. Psychology of Women Quarterly, 32, 277-398.

Morna, C \& Mufune, A. (2005). Media on the a - Gender. Audit of the Southern Africa: Declaration on Gender and Development. Johannesburg: DS Media.

Morna, C. (2002). Promoting Gender Equality In and Through the Media: A Southern African Case Study. Available at: http://www.un.org/womenwatch/daw/egm/media2002/reports/EP5Morna.PDF (Accessed 3rd April 2018)

Nadal, K. L., \& Haynes, K. (2012). The effects of sexism, gender microaggressions, and other forms of discrimination on women's mental health and development. In P. K. Lundberg-Love, K. L. Nadal \& M. A. Paludi (Eds.), Women and mental disorders (pp. 87-101). Santa Barbara, CA: Praeger.

Obiunu, J. (2013). The Effect of Gender Sensitivity On Discrimination Among Secondary School Students. Journal of Emerging Trends in Educational Research and Policy Studies (JETERAPS) 4(6): 888-894. Available at Jeteraps.scholarlinkresearch.org (Accessed 4th April 2018)

Ojukwu, E., Obielozie, E. \& Esimone, C. (2016) Nigerian Values and Contemporary popular music: A new look. Ogirisi: a new journal of African studies Vol. 12s 2016 Available at: http://dx.doi.org/10.4314/og.vl2is1.7 (Accessed 15th August, 2018)

Pan, Z. \& Kosicki, G. (1993). Framing analysis: An approach to news discourse. Political Communication, 10(1), $55-75$

Peter, B. (2001). Equity and Quality: Setting Standards for Women in Journalism. A paper presented in Brussels. Available at www.ifj.org (Accessed 4th April 2018)

Rooney, E. (2016). The Effects of Sexual Objectification on Women's Mental Health. NYU Steinhardt Online Publication of Undergraduate Studies. Available at: https://steinhardt.nyu.edu/appsych/opus/issues/2016/spring/rooney (Accessed 18th August, 2018)

Scheufele, D. (1999). Framing as a theory of Media effects. Journal of Communication, 49 4): 103-22

Senam, N. (2014). Mass Media Law and Ethics (First Edition). Nigeria: Imela Ventures and Publishers Limited.

Sigusch, V. (2004). On cultural transformations of sexuality and gender in recent decades. German Medical Science: GMS E-Journal, 2, Doc07.

Smith, S. \& Granados, A. (2016). Gender and the Media - For Members- National PTA. Available at http://sociology.morrisville.edu/readings/SOCI201/PTA-Gender_and theMedia.pdf (Accessed 6th April 2018)

Smith, S. \& Cook, C. (2008). Female stereotypes: An analysis of popular film and television. Los Angeles, CA: Geena Davis Institute for Gender and Media.

Smith, S. \& Granados, A. (2006). Content Patterns and Effects Surrounding Sex-Role Stereotyping on Television and Film. In J. Bryant \& M.B. Oliver (Eds.), Media Effects. (pp. 324-361). New York: Routledge.

Smith, S., Pieper, K., Granados, A. \& Choueiti, M. (2006). Equity or Eye Candy: Exploring the nature of sexroles in children's television programming. Executive Summary prepared for Dads and Daughters, Duluth, $\mathrm{MN}$. Available at https://seejane.org/wp-content/uploads/equity-or-eye-candy-exploring-nature-sex-roleschildrens-tv.pdf (Accessed 4th April 2018) 
Sribar, R. (2015). Glossary of Common Terms in gender equality and feminist theory. In M. Ule, R. Sribar and A.U. Venturini, eds; Gendering Science: Slovenian Surveys and studies in the EU Paradigms, Vienna Echoraum

Szymanski, D., Moffitt, L. \& Carr, E. (2011). Sexual Objectification of Women: Advances to Theory and Research. The Counselling Psychologist 39(1) 6-38. Available at http://tcp.sagepub.com (Accessed 6th April 2018)

Teachersnetwork.(N.D.) Ethics In $\quad$ Photography $\quad$ II. $\quad$ Available at http://teachersnetwork.org/everywhere/langford/photowebsite/lessons/ethicslesson2/ethics2page6.html (Accessed 3rd April 2018)

Vance, K., Sutter, M., Perrin, P. \& Heesacker, M. (2015). Research on Perceptions of Rape. The Media's Sexual Objectification of Women, Rape Myth Acceptance, and Interpersonal Violence. Pages 569-587. Available at https://doi.org/10.1080/10926771.2015.1029179 (Accessed 8th April 2018)

Verwiebe, R. (2014). Social Institutions in Encyclopaedia of Quality of Life Research. Available at https://www.soz.univie.ac.at/fileadmin/user_upload/inst_soziologie/Personen/Institutsmitglieder/Verwiebe/ Social_Institutions_in_Encyclopedia_of_Quality_of_Life_Research.pdf (Accessed 1st April 2018)

Ward, M. (2016). Media and Sexualisation: State of Empirical Research, 1995-2015. The Journal of Sex Research. Volume 53, 2016 - Issue 4-5: Annual Review of Sex Research. Available at: https://doi.org/10.1080/00224499.2016.1142496 (Accessed 4th April 2018)

Wood, J. (2012). Gendered Media: The Influence of Media on Views of Gender. Available at https://www.nyu.edu/classes/jackson/causes.of.gender.inequality/Readings/Wood\%20$\% 20$ Gendered\%20Media\%20-\%2094.pdf (Accessed 3rd April 2018)

Yamane, T. (1967). Statistics: An Introductory Analysis, 2nd Edition. New York: Harper and Row Publishers.

Yates, D., Moore, D. \& Starnes, D. (2008). The Practice of Statistics, 3rd Ed. New York :W.H. Freeman and Company.

Zeisler, A. (2008). Feminism and Pop Culture. New York: Seal Press. 